\title{
GOVERNING HAJJ: \\ Politics of Islamic Pilgrimage Services in Indonesia Prior to Reformasi Era*
}

\author{
Moch. Nur Ichwan
}

Sunan Kalijaga State Islamic University, Yogyakarta - Indonesia

\begin{abstract}
This article highlights that the hajj (Islamic pilgrimage to Mecca) involves not only religious devotion, but also religious tourism and its associated business, necessary to deal with massive parties of pilgrims, embracing trans-national relations, central and local governments, flight and other travel agencies, pilgrimage guidance units, catering agencies and hotels to the pilgrims themselves in its scope. The aim of this article is to analyse the politics of hajj services, which was carried out mainly through the placing of this pilgrimage under government control, leading to the assumption of its monopoly by the government during the New Order period. Although it will focus on Soeharto period, there will be some discussions on this subject during the colonial and early post-colonial periods to trace the genealogy of government control of haji pilgrimage (and 'umrah, known also as 'small hajij'), especially during the New Order. The author argues that the complexities of hajj (and 'umrah) services were not so much caused by religious aspect but rather by political and economic motives.
\end{abstract}

Keywords: Haij, Umrah, Haij service, politics, religious tourism.

* I would like to thank Herman L. Beck and Abdullahi Ahmed An-Naim who read and gave critical comments on the earlier version of this article. Yet, the views expressed in this article belong solely to the author. 


\section{A. Introduction}

The hajj (Islamic pilgrimage to Mecca) involves not only religious devotion, but also religious tourism and its associated business, necessary to deal with massive parties of pilgrims, embracing transnational relations, central and local governments, flight and other travel agencies, pilgrimage guidance units, catering agencies and hotels to the pilgrims themselves in its scope. The hajj pilgrimage, as Bianchi has said, is: 'A yearlong cycle of planning, financing, teaching, outfitting, transporting, lodging, doctoring, celebrating, mourning, blaming and correcting'. He also remarked that, in one country after another: '... state pilgrimage agencies have taken over the lion's share of the booming market in religious tourism from private business'. ${ }^{1}$ This is also the case of Indonesia, especially since the end of the 1960s, although it can be traced back to earlier period.

The aim of this article is to analyze the politics of bajj services, which was carried out mainly through the placing of this pilgrimage under government control, leading to the assumption of its monopoly by the government during the New Order period. Although it will focus on Soeharto period, there will be some discussions on this subject during the colonial and early post-colonial periods to trace the genealogy of government control of hajj pilgrimage. There will be also some discussion on 'umrah (known also as 'small hajj'), especially during the New Order. I will argue that the complexities of hajj (and 'umrah) services were not so much caused by religious aspect but rather by political and economic motives.

\section{B. Hajj Services in Colonial Era}

The intervention of the state in the regulation of hajj pilgrims dates back to Dutch colonial era. Pilgrims, who were mistakenly called 'Islamic priests', were viewed askance as politically dangerous by the colonial government. The first resolution on the hajj was introduced in 1825 and its purpose was to limit the number of pilgrims as much as possible by charging 110 guilders for a ḅajj passport and imposing a

${ }^{1}$ Robert R. Bianchi, Guests of God: Pilgrimage and Politics in the Islamic World (New York: Oxford University Press, 2004), p. 4. 
fine of 1000 guilders on those who went on the pilgrimage without a passport. The resolution was revised in 1831, and the fine was reduced to twice the cost of the passport cost (220 guilders). Since these two resolutions were applicable only to Java and Madura, in which the government exerted a relatively strong authority, many pilgrims opted to go through Sumatra to avoid the hajj tax. Fearing that the strict regulations on the haij would be counterproductive to its authority, the government repealed both resolutions and introduced a third one in 1852. This resolution maintained the passport but rescinded the hajj tax. This expansive period was short lived and seven years later the government introduced another resolution (in 1859) which set out a far stricter regulation of the pilgrims. This resolution was severely criticized by C. Snouck Hurgronje on the grounds that all the restrictions on hajj affairs would exert a negative effect on Dutch interests in the East Indies. Some restrictions were repealed by Staatsblad 1902 No. 318, and Staatsblad 1905 No. 228. Then, seventeen years later, in 1922, the government issued a new resolution in which possession of an 'obligatory return ticket' was introduced. Although this seems to contradict Snouck Hurgronje's advice, it was in fact related to his suggestion that the pilgrims who stayed in Mecca for a long time were potentially dangerous because they might be contaminated by the possible influence of Pan-Islamism. Some further restrictions were introduced six years late in 1928 in a decree in which it was stated that the government would reject the passport application of suspect persons. ${ }^{2}$ Most of the issues arising from the bajj regulations during this period were closely related to worries about the stability of Dutch colonialism in the East Indies. Pilgrimage to Mecca was seen as the source of political trouble and revolts.

The most relevant point to note in the context of this study is that the hajj services were organized by private agencies. The government merely regulated the haij administration and checked the

${ }^{2}$ On the hajj during Dutch colonial period, see Jacob Vredenbregt, 'The Haddj: Some of its Features and Functions in Indonesia', Bijdragen tot de Taal- Land en Volkenkunde, 118 (1962), pp. 91-154; Daniel van der Meulen, 'The Mecca Pilgrimage and its Importance to the Netherlands East Indies', Muslim World, XXXI (1941), pp. 48-60; see also Dick Douwes and Nico Kaptein (eds.), Indonesia dan Haji (Jakarta: INIS, 1997). 
pilgrims, but was not involved in the organization of haij tourism. It has been only since the eclipse of this colonial regime that the haij has developed into a huge religious tourism business. The three most important private hajj travel agencies in colonial times were Kongsi Tiga, Herklots and Alsegoff \& Co. $^{3}$ Besides these, there were also professional Pilgrim Leaders (Shaykh), who accompanied the pilgrims from their departure from their home country and aided them in many ways, including finding lodgings for them, and Pilgrim Agents (Mutawnif) who were from Mecca and served as a general aid and guide, including, as did Pilgrim Leaders, finding somewhere for them to stay. ${ }^{4}$ Because of the many abuses to which the pilgrims were subjected and other concomitant problems, in the 1920s Muslim organizations, prominent among them are the Muhammadiyah, the Sarekat Islam (SI) and later the Nahdlatul Ulama (NU), attempted to reform bajj services and managed to organize the journey for the hajj by chartering their own ships. The idea was good in principle but these well-intentioned endeavours failed. ${ }^{5}$

During the Japanese occupation and World War II, there was no specific policy relating to the hajj. None of the Dutch regulations concerning the hajj were revised. However, because of the war and the concomitant insecurity and risks travel involved, plus a serious economic decline, neither the Japanese occupation government nor Muslim organizations organized any bajj services.

${ }^{3}$ Dutch documents concerning Herklots and Alsegoff \& Co, during roughly 1893-1911, are published in Arsip Nasional, Biro Perjalanan Haji di Indonesia Masa Kolonial: Agen Herklots dan Firma Alsegoff \& Co (Jakarta: Arsip Nasional Republik Indonesia, 2001).

${ }^{4}$ Ghazy Abdul Wahed Makky, 'Pilgrim Accommodation in Mecca: Spatial Structures, Costs and National Origins', in Ziauddin Sardar and M.A. Zaki Badawi, Haij Studies, (Jeddah: The Hajj Research Centre, King Abdul Aziz University, n.d.), Vol. 1 , p. 62.

${ }^{5}$ On the roles of these Muslim organisations and their leaders, see Laporan Penjelenggaraan Urusan Hadji 1385 H/1965-1966 (Jakarta: Departemen Urusan Haji, 1966), pp. 18-20, hereafter, Laporan (1966); Sumuran Harahap and Mursidi, Lintasan Sejarah Perjalanan Jemaah Haji Indonesia (Jakarta: Intimedia \& Insan Cemerlang, n.d.), pp. 44-5. 


\section{Hajj Services in Post-Independence Era}

During the years immediately following the Declaration of Independence on 17 August 1945, the new Indonesian state had to face the so-called 'second Dutch aggression' (according to Indonesian) or 'police action' (according to the Dutch who were at pains to stress that this was a domestic conflict). At that harrowing time, Masjumi, led by KH Hasjim Asj'ari, issued a fatwa stating that: 'It is haram (forbidden) for Muslims to leave their motherland while it is being attacked by the enemy in order to colonise and destroy religion. Therefore, there is no obligation to perform the hajj when there is fard 'ayn (personal obligation) to go to war against the colonization of nation and religion'. ${ }^{6}$ The fatwa was then endorsed by the MORA Announcement (Maklumat) No. 4/1947 reiterating the same message. Following this, the Minister of Religious Affairs KH Masjkur sent the Hajj Mission I, led by KH Mohammad Adnan, to explain the conditions then current in Indonesia that prevented the organization of hajj services to the Saudi government. ${ }^{7}$

After the end of the war of independence in 1949, the Yayasan Perjalanan Haji Indonesia (PHI-Indonesian Hajj Travel Foundation) was established in 1950, ${ }^{8}$ under the leadership of KH Sudjak (head) and $\mathrm{KH}$ Wahab Hasbullah (deputy-head). Although it was a private institution, it enjoyed the full support of the government. The Minister of Religious Affairs of United Republic of Indonesia in Jakarta, $\mathrm{KH}$ Wahid Hasjim, issued a Letter No. 3170, dated 6 February 1950, and the Minister of Religious Affairs of the Republic of Indonesia at Yogyakarta, KH Faqih Usman, issued Circular (Surat Edaran) No.

${ }^{6} 22$ Tabun Jajasan 'Perdjalanan Hadji Indonesia' dan 50 Tabun Gerakan Perbaikan Perdjalanan Hadji Indonesia (Jakarta: Kantor Pusat Jajasan Pedjalanan Hadji Indonesia [PHI], 1972), Vol. 1, p. 9.

7 The other members of the Hajj Mission I were TM Ismail Banda, Saleh Suaidy, TH Syamsir St. R. Ameh. Bunga Rampai Perhajian II (Jakarta: Departemen Agama RI, Direktorat Jendral Bimbingan Masyarakat Islam dan Penyelenggaraan Haji, 2001), p. 6.

8 The establishment of the PHI Foundation was the realisation of the recommendation made by the Kongres Muslimin Indonesia (Indonesian Muslims Congress), held in 1949. 22 Tahun Jajasan PHI,p. 14. 
A.III/1/648, dated 9 February 1950, stipulating that the only institution recognized by their respective governments to organize hajj services was PHI. Four years later, Minister of Religious Affairs, KH Masjkur, issued a Decree buttressing the previous decrees and establishing the PHI Foundation as the only institution with the proper credentials to work in the field of hajj travel on 13 April 1954 (Ministerial Decision No. 9/ 1954). 'To facilitate arrangements, the Bank Hadji Indonesia (BHI) and the shipping company, Pelajaran Muslimin Indonesia (MUSI), were set up simultaneously. Because of the precarious financial situation in Indonesia, MUSI did not have its own ships but chartered them from other shipping companies. The Majelis Pimpinan Haji (MPH—Council for Hajj Guidance) was also established to instruct the prospective pilgrims and guide them during the pilgrimage.

During the so-called Guided Democracy period when the doctrine of NASAKOM (Nasionalisme, Agama, KomunismeNationalism, Religion, Communism) was being promulgated, Soekarno tried to introduce some 'reforms' in hajj services. His attempts can be classified into several phases. In the first phase, 1959-1962, the government (in the shape of MORA) tried to extend a hegemony over the national organization of the bajj, by privatizing PHI, which became a semi-governmental institution within MORA but dominated by Muslim leaders. The Junior Minister of Religious Affairs KH Wahib Wahab issued Decree No. 36/1959, dated 15 August 1959, on the Position of PHI and/or Withdrawal of Recognition of PHI as the Only Institution Working in Indonesian Hajj Travel Affairs under the Protection and Supervision of the Ministry of Religious Affairs. ${ }^{10}$ The decree came into force on 1 September 1959. As the title of the decree indicates, it announced that PHI's privilege as the only institution with the authority to organize the hajj service had been allowed to lapse and that PHI had been transformed into a fully private foundation (yayasan partikelir). The relationship between MORA and PHI was merely a

9 The Decision is reprinted in Risalah Musjawarah Kerdja Urusan Hadji Selurub Indonesia ke-VI, Tgl. 27 s/d 30-4-1972 di Jakarta, (Jakarta: Direktorat Djendral Urusan Hadji, 1972), pp. 234-7; hereafter, Risalah. In this period, KH M. Dachlan was in charge of PHI, Ibid., p. 239.

${ }^{10}$ The Decree is reprinted in Risalah, pp. 267-9. 
commercial one. From then on, with its wings clipped, a curtailed PHI was restricted to arranging local travel between ports (before and after

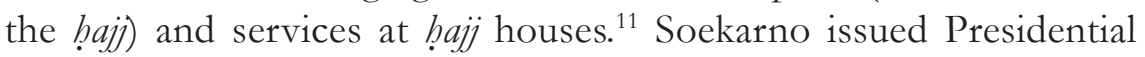
Decree No. 3/1960 on Haij Services. The decree stipulated that hajj services were organized by the government: by the Junior Minister of Religious Affairs and Minister of Foreign Affairs. ${ }^{12}$ In 1962, MUSI and the Bank Haji were dissolved. PHI teetered on the brink of dissolution, but was defended by a number of Muslim leaders. ${ }^{13}$ Noer argued that the dissolution of MUSI and the Bank Haji was related to the banning of Masjumi in 1960 (because of the alleged involvement of some of its leaders in the PRRI/Permesta revolt), on the grounds that many members of PHI and MUSI were Masjumi members. ${ }^{14}$ This controversial policy elicited severe criticism from Muslim leaders, especially those involved — directly or indirectly—in the so-called 'ḅajj travel reform' movement.

The second phase, 1962-1964, was one in which the government proposed a new concept of hajj services reform. The reason for this was that the previous policy had done nothing to improve bajj services, and nor putting any fine point on it too, the policy had also deteriorated it . The role of the Coordinating Minister for Public Welfare, Muljadi Djojomartono, who had also played a role in hạj reform during Dutch era, was vital. Now, contrary to his role in the pre-independence era,

${ }^{11}$ See letter of the head of the Haij Affairs Section of MORA to central PHI on Manasik Haji Training, dated 17 October 1959; and the letter of the Jumior Minister of Religious Affairs to the Central Board of the PHI Foundation on the Tasks of PHI during the Hajj 1960, dated 26 October 1959. The details of the cooperation were properly formulated in 1960, when the Junior Minister of Religious Affairs issued a latter on Tasks Allotted By the Ministry of Religious Affairs RI to the Perdjalanan Hadji Indonesia on Hajj Travel of 1960, dated 14 January 1960. These documents are reprinted in Risalah, pp. 270-2 and 242- 7 respectively.

${ }^{12}$ Harahap and Mursyidi, Lintasan Sejarah, p. 130.

${ }^{13}$ These Muslim leaders were: Dr. KH Idham Chalid, KH Musta'in, KH Fakih Usman, KH Ahmad Badawi, KH Roesli Abd. Wahid, Muljadi Djojomartono and KH Saifuddin Zuhri; 22 Tahun Jajasan PHI, p. 23.

${ }^{14}$ Deliar Noer, Administrasi Islam di Indonesia, new edition, Jakarta: PT. Rajawali, 1983), pp. 104-6. In this Indonesian version, Noer updated some data until 1980. The English version covers only the development of Islamic administration, including hajj services, until 1978. 
Djojomartono now acted as a government representative. He was appointed as the head of the Panitia Perbaikan Perjalanan Haji (P3HCommittee for the Reform of the Haij Travel Arrangements) by Soekarno in $1962 .{ }^{15}$ This committee was entrusted with two important tasks: 1) a short-term task, consisting of formulating guidelines for and defining the respective scopes of government and private agencies and institutions in hajj affairs, and formulating the major technical tasks to be tackled in running hajj services; 2) a long-term task, amending the 1922 Hajj Resolution and other Dutch colonial regulations on the bajj, introducing statutory regulations which were in accordance with the 1945 Constitution. ${ }^{16}$ With the 'moral support' of the Minister of Religious Affairs, Prof. KH Saifuddin Zuhri, P3H invited the PHI foundation to play a role again in national hajj services. ${ }^{17}$ In this phase the cooperation between the government and the private hajj institution (PHI) was restored.

In the third phase, 1964-1966, the authority of the government was expanded, and the role of private agencies and institutions was centralized in the government-supported PHI and PT Arafat. This was authorized by Presidential Decree No. 122/1964 on The Organization of Haij Services, dated 5 May $1964 .{ }^{18}$ Under the terms of this decree, MORA was no longer the only government player in hajj affairs. It seems likely that the decree was issued in anticipation of the involvement of the Coordinating Minister for Public Welfare, which later grew more prominent. This Presidential Decree states that 'The organization of hajj services is a national duty, and therefore it falls under the authority of the Coordinating Ministry of Public Welfare'. This was not the only change instigated by the Decree. P3H was replaced by a new institution, namely the Dewan Urusan Haji (DUHA-Board for Haij Affairs), which was led by Djojomartono. As the head of DUHA, he was the main architect of the establishment of

${ }^{15}$ Based on Presidential Decree No. 290/1962, dated 6 September 1962; reprinted in Risalah,pp. 284-5.

${ }^{16}$ Laporan (1966),p. 20.

${ }^{17} 22$ Tabun Jajasan PHI, p. 23.

${ }^{18}$ The decree is reprinted in Risalah,pp. 286-8. 
PT Arafat, ${ }^{19}$ a hajj agency set up on 1 December $1964,{ }^{20}$ in which he was the head of the Representative Board of Share Holders.

The role of the Coordinating Minister, who was also ex-officio the head of DUHA, grew more powerful. This was patently revealed in two instances. First, the issuance of the Decree No. 08/1964 stipulating that the organization of hajj services at the local level was to be undertaken by the regional governments. This role was merely coordinating and was not in anyway structural. A regulation such as this was usually issued by the Minister of Religious Affairs either alone or in collaboration with the Minister of Home Affairs. Second, on 28 October 1964, Djojomartono as the Coordinating Minister of Public Welfare/Head of DUHA delivered his historic Radio Speech on 'the Purchase of HajjShips by the Coordinating Minister of Public Welfare/ Head of DUHA', on 28 October 1964. In this speech, Djojomartono stated that: 'The order of the President to the Dewan Urusan Haji [DUHA] to purchase special hajj ships would be realized ...by using pilgrims' own money... Each hajj candidate who applies this year will be obliged to give their share to the Bank Indonesia in Jakarta... Those who did not send the money would have their application rejected'. He also said: 'Like other shares, at certain times dividends or profits would be shared, if PT [Arafat] made a profit'. ${ }^{21}$ About two months later, PT Arafat, which was responsible for purchasing and managing

${ }^{19}$ Before proposing the establishment of PT Arafat to the President, Muljadi Djojomartono discussed it with KH M. Dachlan and A. Musaffa Basjyr. See 22 Tahun Jajasan PHI, p. 24.

${ }^{20}$ Noer mistakenly mentioned that PT Arafat was established in 1961. Therefore, his criticism of this company prior to its establishment in 1964 is not valid. Noer, Administrasi Islam, p. 107.

21 'Pidato Radio J.M. Menko Kesejahteraan/Ketua Dewan Urusan Haji, H.M. Muljadi Djojomartono tentang Pembelian Kapal-kapal Haji', Jakarta, 28 October 1964, reprinted in Harahap and Mursyidi, Lintasan Sejarah, p. 164-7. The application for bajj was opened on 5 September 1964. Up to 27 October 1964, there were 68,181 haij candidates who paid their share. 
the haij ships, was established. ${ }^{22}$ Although not officially stated, MORA handled the administrative side of things, whereas the Coordinating Minister for Public Welfare dealt with practical matters pertaining to hajj services through $\mathrm{P} 3 \mathrm{H}, \mathrm{DUHA}$, and PT Arafat. The later was a result of the fact that Djojomartono was the representative of both the government and the private agency.

After the failed coup allegedly launched by the PKI in 1965, in what became known as the 'Hundred Ministries Cabinet', Soekarno established a special Ministry of Haij Affairs (in Presidential Decree No. 180/1965), on 19 June 1965, with Prof. KH Farid Ma'ruf as its minister. The ministry was responsible for: (1) deciding policies concerning the hajj services; (2) managing the hajj services and overseeing everything related haij affairs both in the home country and abroad; (3) improving the education of hajj candidates by raising their religious awareness and improving their knowledge, especially on the subject of the haij and the national persona; (4) guiding the 'souls' of pilgrims after their return home: 'So that they are useful to their religion, their nation and their state'. ${ }^{23}$ During this period, the role of MORA in this was limited to issuing statements concerning mahram at the time of application. In 1965, the Minister of Haij Affairs issued Decree of the Minister of Haij Affairs No. 16/1965 to boost

${ }^{22}$ PT Arafat managed seven ships: the Gunung Djati, the Tjut Njak Dhien, the Ambunombo, the Pacific Abeto, the Belle Abeto, the Le Havre Abeto, and the La Grande Abeto. However, it seems that most of the ships were hire-purchased, with the exception of the Tjut Njak Dien (formerly named Princes Irene), which was bought from a company in the Netherlands. Here, another ministry, the Ministry of Maritime Transportation, was involved. The status of the ships was, in fact, not clear. The Decree of the Minister of Maritime Ali Sadikin (No. Kab.4/19/8), dated 13 July 1965, granted the 'authority' (penguasaan) and 'management' (pengusahaan) of the Tjut Njak Dhien to PT Arafat. The other decrees were issued for granting the authority and management of the Gunung Djati and the Ambunombo to PT Arafat. This means that PT Arafat was in fact not the owner of the ships. See 'Keputusan Menteri Perhubungan Laut, No. B.M. 2/2/21', Jakarta, 20 October 1965, and 'Keputusan Menteri Perhubungan Laut, No. DRP.4/1/ 3', Jakarta, 12 January 1966, both reprinted in Harahap and Mursyidi, Lintasan Sejarah, p. 178-181; Laporan Penjelenggaraan Urusan Hadji Tahun 1386 H/1966/67 M dan Tabun 1387 H/1967/68 M (Jakarta: Direktorat Djendral Urusan Hadji, 1968), p. 33; hereafter, Laporan.

${ }^{23}$ Harahap and Mursyidi, Lintasan Sejarah, p. 184. 
the position of PHI as a government partner in managing bajj affairs at local and national level. ${ }^{24}$ However, from April 1966, the Ministry of Hajj Affairs place under the aegis of a 'Deputy Minister', who in fact the same person, Prof. KH Farid Ma ruf. ${ }^{25}$ Yet, two months later, on 4 August 1966, the ministry was dissolved by Presidential Decree No. 170/1966 and transformed into the Directorate General of Haij Affairs under the administration of MORA. ${ }^{26}$

One of the new developments in hajj services in this period was the emergence of the so-called Haji Berdikari (Independent Pilgrims), that is: 'Those who go on the hajj pilgrimage using their own foreign exchange...to cover their expenses during their pilgrimage in Saudi Arabia and have Rupiah currency to take a return ship from Jeddah to Indonesia'. ${ }^{27}$ At that time, foreign exchange was provided by the government through the Indonesian Embassy in Jeddah. Those who had their own foreign exchange (at least \$100) could arrange their own bajj. However, they were obliged to register with MORA, and the quota for Haji Berdikari was decided by MORA. ${ }^{28}$ This programme relieved the candidate pilgrims of the long and complicated procedure of haij registration.

\section{Governing Hajj in New Order Era: Establishing Monopoly}

The first three years after the establishment of the New Order regime in 1966, the government continued the previous policies on hajj affairs. It was reported that many candidate pilgrims failed to make the pilgrimage because of the mismanagement of such 'irresponsible private hạj agencies and brokers', as Mukersa Haji, Al-Ichlas ḥajj agency, and YAMU'ALIM (Yayasan Mu'awanah lil Muslimin). To overcome the problem, the government decided not only to increase the involvement of the state in hajj affairs, but in fact to go as far as to assume a monopoly on hajj affairs, by issuing Presidential Decree No.

\footnotetext{
${ }^{24}$ On the details of the PHI's tasks, see 22 Tabun Jajasan PHI, pp. 26-7.

${ }^{25}$ On the basis of Presidential Decree No. 4/1966.

${ }^{26}$ Laporan, pp. 1, 69.

${ }^{27}$ Haji Berdikari was regulated by the Decree of the Minister of Religious Affairs No. 73/1966, dated 27 October 1966.

${ }^{28}$ Harahap and Mursidi, Lintasan Sejarah, pp. 218-20.
} 
22/1969 on Haij Services by the Government on 7 March 1969. ${ }^{29}$ Article 1 of the Decree reads: 'The whole organization of baij services will be conducted solely by the government according to the stipulations laid down in this Presidential Decree'. This was then elucidated by Presidential Instruction No. 6/1969 on the Implementation Guidance of the Services of Haij Affairs, dated 24 March 1969, which stated that all services pertaining to hajj affairs organized by the government were: the decision on the hajj quota; share in the quota; cost of hajj services; registration of hajj candidates; receiving the costs of hajj services; issuing a passport; delivering pilgrims; protecting the health, safety, and security of haij journeys to and from the Holy Land; protecting the safety and security of pilgrims' baggage; and other activities related to hajj affairs. Article 1 item (3) reads: 'Private agencies and individuals are not allowed to organize activities related to hajj affairs as described in Article 1 of this Instruction'. ${ }^{30}$

This monopoly policy on hajj services was criticized by many Muslim leaders who interpreted it as an attempt to shut out the involvement of private hajj agencies, or even, as Sjafruddin Prawiranegara, the chairperson of HUSAMI, stated: 'To hamper bajj observance... [and] ...hinder Muslims from visiting Masjid al-Haram, to accomplish the hajj ${ }^{31}$

In his speech delivered at the commemoration of Isra' Miraj at the State Palace on 9 October 1969, President Soeharto responded to this criticism. He said:

In relation to this [policy on haj]], again, I would like to emphasize that the government does not intend to restrict the Islamic ummah's freedom to accomplish their religious obligations in any way whatsoever; instead, the government wants to establish some order in the hajj, protecting the Islamic ummab from the malpractices of certain private agents who had caused dissatisfaction and loosed among hajj candidates....

\footnotetext{
${ }^{29}$ Reprinted in Risalah, pp. 289-91.

30 'Instruksi Presiden Republik Indonesia No. 6 Tahun 1969', Jakarta, 24 March 1969, reprinted in in Risalah, pp. 292-6.

${ }^{31}$ See Sjafruddin Prawiranegara, Djangan Mempersulit Ibadah Hadji (Jakarta: DPP HUSAMI, 1970), p. 17.
} 
I call on hajj candidates not to be enticed by and drawn to private enterprises that defy government policy, so that they will not be disappointed afterwards. ${ }^{32}$

However, despite the prohibition, HUSAMI organized a hajj journey by sea in 1970, in which almost 1000 pilgrims took part. Sjafruddin Prawiranegara denied that HUSAMI had violated the Presidential Decree and Instruction. On the offense, he alleged that both the decree and the instruction were in violation of the 1945 Constitution Article 29 and Decision of the Provisional People's Consultative Assembly (MPRS) No. XXVII and XXIII of 1966..$^{33}$

On 4 December 1974, the aircraft chartered from the Dutch company Martinair, by Garuda Indonesia Airlines, crashed in Colombo, Sri Lanka. The number of victims who lost their lives was 182 pilgrims, 9 crew members plus 2 pramugari and pramugara recruited from IAIN. Minister of Religious Affairs Abdul Mukti Ali made an announcement on the national television station, TVRI (Televisi Republik Indonesia), and the national radio station, RRI (Radio Republik Indonesia), on 6 December 1976, explaining all matters relating to the tragedy, including expressing his hope that Muslims believed that this was the destiny allotted by God and that the victims were 'syuhada' haji' (bajj martyrs). ${ }^{34}$

Beginning in 1978 bajj travel was organized exclusively by plane, because PT Arafat had ceased to operate. ${ }^{35}$ The official reasons given were that it was in the throes of a management reform and consolidation. There were four national airline companies involved:

${ }^{32}$ Quoted in Laporan Penjelenggaraan Urusan Hadji Tabun 1388 H/1968/69 M dan Tahun 1389 H/1969/70 M (Jakarta: Direktorat Djendral Urusan Hadji, 1970), p. 257.

${ }^{33}$ Prawiranegara, Jangan Mempersulit, pp. 18, 21.

${ }^{34}$ See: 'Keterangan Menteri Agama tentang Kecelakaan Pesawat D.C. Martin Air yang Mengangkut calon Jemaah Haji Indonesia, tgl. 4 Desember 1974', Jakarta, 5 June 1975; and 'Pengumuman Pemerintah', Jakarta, 6 December 1974; both reprinted in: Himpunan Risalab Rapat Kerja Urusan Haji Selurub Indonesia ke-XIV di Cisarua Bogor, 2730 January 1982 (Jakarta: Direktorat Jenderal Bimbingan Masyarakat Islam dan Urusan Haji, Departemen Agama RI, 1982), pp. 242-9 and 250-1 respectively; hereafter, Himpunan Risalah.

${ }^{35}$ This was based on Presidential Decree No. 10/1978 on the Cost of Haij Services 1978/1979. 
PT Garuda Indonesia Airways (GIA); Merpati Nusantara Airlines; Mandala; and Bouraq. However, in practice, because of the shortage of aircraft, they were allowed to charter aircraft from other international airlines. On 15 November 1978, the so-called 'Colombo Tragedy' reoccurred when an Icelandic Loftleider plane, chartered by GIA, crashed at Katunayake International Airport Colombo. One hundred and seventy-six pilgrims (out of 262) and eight airline crew were killed. ${ }^{36}$ Again, MORA declared the victims were 'syubada" (martyrs).

In 1979, PT Arafat was declared bankrupt. Therefore, ḩajj by ship was officially abandoned, and thereafter bajj travel was organized solely by plane. ${ }^{37}$ However, traumatized by the Colombo Tragedy, many Muslim leaders and members of the legislature proposed that hajj transportation by ship to be restored. They argued that making the haij by ships was 'safer' than by airplane: '...the pilgrims have more time to prepare themselves physically and spiritually'. It was considered 'more appropriate for Indonesian lay pilgrims, [and] ...the pilgrims are able to take more luggages'. Despite the cogency of their arguments, the government did not agree, and decided to continue to limit bajj travel to transportation by airplane for reasons of effectiveness and efficiency. ${ }^{38}$

At the beginning of the 1980s, the government re-emphasized its authority to take charge of the organization of hajj services. Soeharto issued Presidential Decree No. 53/1981 on Haij Services (hereafter, the 1981 PDHS). ${ }^{39}$ It contained three important points:

1) The organization of hajj affairs was a national duty and conducted only under the aegis of the government;

2) The organization of bajj affairs was carried out with the coordination and under the responsibility of the Minister of Religious Affairs;

${ }^{36}$ Amiruddin Siregar, 'Bagaimana Haji 1978 dan Haji 1979', Mimbar Ulama, no. 26, January 1979, p. 52.

${ }^{37}$ These were based on the Decree of the Minister of Transportation No. SK72/OT.001/Phb-79. Achmad Nidjam and Alatief Hanan, Manajemen Haji: Studi Kasus dan Telaab Implementasi Knowledge Workers (Jakarta: Zikrul Hakim, 2001), p. 40.

${ }^{38}$ Siregar, "Bagaimana Haji", pp. 56-7.

${ }^{39}$ The decree is reprinted in Kebijaksanaan Menteri Agama RI di Bidang Haji (Jakarta: Proyek Perencanaan Peraturan Perundangan Keagamaan Biro Hukum dan Humas Departemen Agama, 1981/1982), pp. 63-9. 
3) The cost of making the hajj (ONH, Ongkos Naik Haji) was to be decided by the President basing his assessment on the proposal of the Minister of Religious Affairs, after also having won the opinion of the Ministry of Finance. ${ }^{40}$

The 1981 PDHS was in fact an echo of the previous Presidential Decree of 1969. The government, especially MORA, had a monopoly on the expedition of hajj affairs. As mentioned in Decree of the Minister of Religious Affairs No. 2/1982, when it organized matters pertaining to the hajj, MORA was expected to cooperate, horizontally, with other ministries, namely those of: Home Affairs, Health, Transportation, Foreign Affairs, Justice, Finance, Trade and Cooperation, Defence and Security, and Information. Vertically, MORA had to collaborate with the governors and bupatis as the provincial and district organizers of bajj. The involvement of these other ministries and government offices was necessitated by the stipulation that 'the organization of hajj affairs is a national duty'.

In the spirit of the times, Minister of Religious Affairs Alamsyah Ratu Perwiranegara related the hajj to development. In his speech at the closing ceremony of the Working Conference on Haij Affairs in 1982, he stated that: 1) The haij is one of the links in the chain of the process of development of 'fully rounded Indonesian people' (manusia Indonesia seutubnya), and therefore contributes towards the maturation of a nation which is progressive (maju), faithful (beriman) and Godfearing (bertaqwa); 2) bajj officials are real servants of the bajj working in the spirit of public service without any attempt to accrue themselves material benefits; 3) Offering bajj service is an act of religious devotion ( $i b a d a$ ) and if the hajj officials are sincere (ikblas) in carrying out their work, they will be rewarded (in the Hereafter). ${ }^{41}$ The first point summed up the ideological doctrine of the New Order, which was to become a major slogan in the 'development of religious affairs' (pembangunan agama). The second and the third emphasized the devotional nature of bajj services.

${ }^{40}$ See Articles 1, 2 and 4 of the 1981 PDHS.

41 'Amanat Menteri Agama RI pada Upacara Penutupan Rapat Kerja Urusan Haji ke-XIV Tanggal 30 January 1982/ 5 Rabi'ul Akhir 1402 di Cisarua Bogor', reprinted in: Himpunan Risalah (1982), pp. 230-4. 
At the end of the 1980s, the government re-opened the gate for the limited involvement of the private agencies in hajj services, under the auspices of MORA. This was based on Decree of the Minister of Religious Affairs No. 22/1987 on Decision of the Organization of $\mathrm{ONH}$ Plus Pilgrimage. This led to the emergence of the so-called ' $\mathrm{ONH}$ Plus' pilgrims or haij plus, ${ }^{42}$ a special hajj service organized for middleclass Muslims who felt in need of special treatment and facilities during the bajj. The ONH plus pilgrims were those registered as 'ordinary' pilgrims at MORA but who then re-applied to the private hajj agencies for special treatment and facilities against the payment of the extra costs decided by the agencies. This new way of making the bajj began to win favour among the Muslim middle class at the end of the 1980s.

The year 1990 witnessed a tragic accident in the Muaisim Tunnel, Mina, Saudi Arabia, in which more than 600 Indonesian pilgrims died. It became known as the 'Mina Tragedy' and the victims have gained recognition as 'syuhada' Mina' (the Martyrs of Mina). ${ }^{43}$ This tragedy had two important upshots. The first was the establishment of Haij Hospitals (Rumah Sakit Haji) in Medan, Ujung Pandang, Surabaya, and Jakarta 'as monuments to commemorate the Mina Tragedy'. ${ }^{44}$ The second was that Soeharto decided to perform hajj pilgrimage himself in 1991, accompanied by his family and some of his ministers. This was a great political landmark, signifying his growing inclination towards Islam which had become more apparent since the end of the $1980 \mathrm{~s}^{45}$ Many Islamic organisations expressed their happiness at Soeharto's personal decision to make the bajj. A new 'non-official' name 'Haji Muhammad Soeharto' was associated with him, especially when he addressed Muslim communities. Although considered appropriate on such religious occasions, this new name was not used for official

${ }^{42} \mathrm{ONH}$ is the abbreviation of Ongkos Naik Haji (cost of pilgrimage).

${ }^{43}$ On the Mina Tragedy, see Heru Soeyono, Musibah Terowongan Al-Muaishim Haratul Lisan Mina (Klaten: Yayasan Ki Juru Mertani, 1990); Nur Cholis Huda, Kisah Musibah Terowongan Mina (Surabaya: Bina Ilmu, 1990).

${ }^{44}$ See Rumah Sakit Haji Jakarta (Jakarta: Rumah Sakit Haji Jakarta, 1994), pp. 134; hereafter, Rumah Sakit, Mimbar Pembangunan Agama, No. 80, May 1993, pp. 24-5.

${ }^{45}$ On the journalistic reports about Soeharto's pilgrimage, see Tim Penyusunan dan Penerbitan, Perjalanan Ibadah Haji Pak Harto (Jakarta: Departemen Agama RI, 1993). 
documents. After he had shown the way, the haij pilgrimage became popular among government officials and political figures, and triggered the emergence of what became known as 'political hajj (baji politik).

The growing number of pilgrims, especially those from the middle class, fuelled the development of the hajj tourism business. ${ }^{46}$ This prompted the government to improve the regulation on the ' $\mathrm{ONH}$ Plus'. The Minister of Religious Affairs issued Decree No. 245/1991 on the Organization of 'ONH plus', dated 1 October 1991. ${ }^{47}$ This contained the rules for making an application for $\mathrm{ONH}$ Plus and regulated departure to and from the Holy Land, setting out rules that the private hajj agencies were expected to follow. The Achilles heel in this decree was that it did not regulate the ONH Plus organizers. Therefore it was necessary to promulgate yet another Ministerial Decree No. 246/1991 on the Appointment of 'ONH Plus' Organizers in 1992. This was issued on 21 November 1991 for the purpose of designating thirteen bajj agencies and fixing certain rules for the running of their business. $^{48}$

The organization of ONH Plus pilgrimage in 1992 was best filled with host of problems. The organizers booked their clients on the regular hajj flights which caused problems for regular hajj services. It also meant that there were unequal prices, an excess of the quota, and some pilgrims were simply handed over to other organizers. Embarrassed by these problems, Minister Munawir Sjadzali issued Decree No. 218/1992 on the Decision of the Organization of the

${ }^{46}$ On the anthropological study of the ' hajj plus', see Moeslim Abdurrahman, 'On Hajj Tourism: In Search of Piety and Identity in the New Order Indonesia', PhD Dissertation, (Urbana-Champaign: the Graduate College of the University of Illinois, 2000).

47 'Keputusan Menteri Agama Republik Indonesia Nomor 245 tahun 1991 tentang Penyelenggara Urusan Haji ONH Plus', Jakarta, 1 October 1991; reprinted in Himpunan Peraturan Perundang-undangan Ditjen Bimas Islam dan Urusan Haji (Jakarta: Direktorat Jendral Bimbingan Masyarakat Islam dan Urusan Haji, Departemen Agama RI,1993), pp. 984-9.

${ }^{48}$ Darul Aqsha, Dick van der Meij, and Johan Meuleman, Islam in Indonesia: A Survey of Events and Developments from 1988 to March 1993 (Jakarta: INIS, 1995), p. 118. 
ONH Plus Pilgrimage of 1993, which laid down tighter regulations. ${ }^{49}$ Strong sanctions were imposed on any organizers who violated the Decree. Their permit might be withdrawn or might not be extended.

The significant development in the numbers participating in the bajj at the beginning of the 1990s necessitated the introduction of a new regulation. To rectify the situation, Soeharto issued Presidential Decree No. 62/1995 on the Organization of Haij Services, which, in the vein of previous regulations, emphasized the government monopoly in this business by stipulating that: 'The organization of haij affairs is a national duty and is undertaken only by the government'. ${ }^{50}$ The 'bajj affairs' considered the responsibility of the government and stated in the decree that its duties were: the planning of the organization of the hajj; deciding the cost of hajj; accepting and registering the pilgrims; checking, serving and protecting the health of pilgrims; receiving and managing the costs of the bajj; arranging the bajj passports; arranging for training for and guidance of the pilgrims; managing the safety, order and material welfare of pilgrims during the duration of the hajj; taking care of the accommodation for the pilgrims; managing the transportation of the pilgrims; ensuring the proper delivery and security of the pilgrims' luggage; controlling the administrative and technical matters pertaining to the organization of hajj affairs; overseeing the organization of hajj; and any other activities related to the successful conclusion of the hajj. ${ }^{51}$ This covers almost the entire scope of the organization of haij services, and all of these activities were to be centered at MORA.

The mid-1990s was marked by a boom in the hajj. In 1995, something in the order of 231,000 persons applied to undertake hajj, exceeding the quota given by the Saudi government, 195,000 pilgrims, by nearly 40,000 . The international quota of pilgrims was decided by Saudi Government on the basis of the agreement reached at the 1987 Organization of Islamic Conference (OIC) in Amman which stipulated

${ }^{49}$ In this year Government also established the Centre for Hajj Information on 23 February 1993 in Jakarta. The same centre was established in Surabaya, Medan, Ujungpandang and Bandung. Mimbar Pembangunan Agama 80 (May 1993), p. 69.

${ }^{50}$ Article 1 of the Presidential Decree No. 62/1995.

${ }^{51}$ Article 2 of the Presidential Decree No. 62/1995. 
that a country could send only 0.1 per cent of its Muslim population on the hajj each year. ${ }^{52}$ The upshot of this quota policy was that many pilgrim candidates failed to make hajj that year, and were obliged to wait until the next year. Alerted by this event, MORA developed the Sistem Komputerisasi Haji Terpadu (SISKOHAT_Computerized Integrated System of Hajj), supported by the Information System Bureau of the PT. Garuda Indonesia and Banking Technological System Bureau. ${ }^{53}$

\section{E. 'Umrah Travel as Private Enterprise: Government as Regulator}

In contrast to matters pertaining to the bajj, which fell entirely under the aegis of the government, the organization of the "umrah was handed over to private agencies, especially those which specialized in organizing collective pilgrimages. Individual pilgrims were also allowed to arrange their own 'umrah journey. The government (MORA) functioned merely as regulator. By 1979, this system was in need of revision and hence regulation of the 'umrah was enacted in 1979, when MORA and the Ministry of Justice issued a Joint Decree on 'umrah Services. This step was prompted by the fact that a number of 'umrah pilgrims did not come straight back but lingered on in Mecca until the Hajj month in order to make the hajj. This produced big problems for both the Saudi and Indonesian governments, because many of them found themselves in severe financial straits because they did not have the wherewithal for their daily needs, let alone the money to purchase a ticket home. However well-intentioned they were, the regulations did not put an end to the practice.

${ }^{52}$ Indonesia, with about 135 million Muslims in the 1980s, could send 135,000 pilgrims. Aqsha et al, Islam in Indonesia, p. 115. In the mid-1990s the quota was 195,000. Nidjam and Hanan, Manajemen Haji, p. 47; Makoto Ito, 'Haji Tour under the Late New Order Regime in Indonesia: South Sulawesi Case', unpublished paper, n.d., p. 3.

${ }^{53}$ Interview with Dr. Tarmizi Taher, Jakarta, 12 August 2004. On SISKOHAT, see: Departemen Agama, Era Baru Perhajian Melalui Sistem Komputerisasi Haji Terpadu (SISKOHAT) (Jakarta: Direktorat Jenderal Bimbingan Masyarakat Islam dan Urusan Haji, Departemen Agama RI, 2000). 
At the beginning of the 1980s, "umrah was being pretty effectively regulated by the government. Nevertheless, the earlier stratagem of protracting the 'umrah until the month of the hajj was still widely resorted to because of the high cost and complicated procedures involved in going on the hajj. In 1983, it was reported that the number of 'unofficial hajj' (haji gelap) who managed to perform the hajj by overstaying after their 'umrah amounted to 24,000 compared to 50,000 official hajj in that same year. ${ }^{54}$ In 1983, Soeharto issued Presidential Decree No. 63/ 1983 on 'umrah. Although the decree stipulated unequivocally that: 'The organization of 'umrah travel is not in the hands of the government of the Republic of Indonesia', it also forestalled the possible overstay of 'umrah pilgrims until the hajj month. ${ }^{55}$ Umrah pilgrimage could be undertaken by individuals, including those with family members as long as these did not exceed five, or in group, which should be organised by 'umrah travel agencies (Penyelenggara Perjalanan Umrah) recognized by the Minister of Religious Affairs. There was no tight regulation of individual 'umrah pilgrims, except exacting that they should promise to return soon after completing the 'umrah, be in possession of a health certificate issued by a government doctor and have enough money to cover their costs during the pilgrimage. ${ }^{56}$ The requirements placed on the "umrah travel agencies were strict, and included such measures as having to draw up an itinerary; managing to send and bring back the pilgrims according to plan; completing the travel documents; arranging accommodation and health care; managing the purchasing and ensuring the availability of tickets from and to the hometown of the pilgrims; giving proper training in and guidance about 'umrab; and making a report on their 'umrah services to the Minister of Religious Affairs. ${ }^{57}$ Sanctions were also imposed on those which violated the decree, but these were

${ }^{54}$ See: 'Umroh Ditata, Haji Kena', Tempo, 21 January 1984; François Raillon, 'The New Order and Islam, or the Imbroglio of Faith and Politics', Indonesia, no. 57, 1994, p. 205.

${ }^{55}$ Article 2, point 2, of the Presidential Decree No. 63/1983. The decree is reprinted in Buku Pegangan Penatar/Penyulub Calon Haji (Jakarta: Direktorat Jenderal Bimbingan Masyarakat Islam dan Urusan Haji, Departemen Agama RI, 1988), pp. 303-9; hereafter, Buku Pegangan.

${ }^{56}$ Article 5 of the Presidential Decree No. 63/1983.

${ }^{57}$ Article 7, item 1, of the Presidential Decree No. 63/1983. 
not specified in detail. They were simply referred to as 'sanctions according to the statutory regulations' ${ }^{58}$ To ensure the necessary regulation of the private umrah travel agencies, the Minister of Religious Affairs issued Decree No. 1/1984, which stipulated further requirements for opening an 'umrah travel agency and the potential sanctions for violating the rules. ${ }^{59}$ Moreover, the itinerary devised and the subsequent report on 'umrah travel organized by private agencies were also placed under stricter regulation. ${ }^{60}$ Other ministries which had a finger in the pie also issued regulations concerning 'umrah: the Ministry of Justice issued Instruction No. M.01-UM.01.06 year 1984 on the Immigration Procedure of 'umrah Travel, on 23 February 1984; the Ministry of Tourism, Post and Telecommunication issued Decree No. KM.19/PW.102/MPTT-84 on the Requirements for the Appointment of Public Travel Bureau as 'umrah Travel Organizers, on 27 February 1984. In the case of 'umrah, in principle, the regulations stipulate that "umrab is to be undertaken outside the month of bajj (as well as two months before and one month after it), and it could be done individually or collectively. The aim of all these regulations was to enhance the quality of umrah services offered by private agencies.

Encouraged by the growing 'umrah travel business, many private umrah travel agencies were opened. Many agencies did not confine their activities to organising the 'umrah pilgrimage, but also offered the opportunity to visit other religious sites in the Holly Land, and even the Al-Aqsa mosque in Jerusalem. On 21 November 1991, the Minister of Religious Affairs issued Decree No. 280/1991 designating twentythree private agencies to organize 'umrah travel, including the thirteen agencies involved in the 'ONH Plus'. ${ }^{61}$

${ }^{58}$ Article 12 of the Presidential Decree No. 63/1983.

${ }^{59}$ The decree is reprinted in Buku Pegangan, pp. 310-4. The decree was based on the meeting between the Ministries of Home Affairs, of Transportation, of Tourism, Post and Telecommunication, of Justice, of Foreign Affairs, of Health and of Religious Affairs on 13 February 1984.

${ }^{60}$ See the Decree of the Minister of Religious Affairs No. 12/1984 on Plane and Report of 'Umrah' Travel Organisation, reprinted in Buku Pegangan, pp. 320-7.

${ }^{61}$ Aqsha et al, Islam in Indonesia, p. 122. 
On 15 July 1996, Soeharto issued Presidential Decree No. 57/ 1996 on 'Umrah Travel Organization, to regulate 'umrah travel by private agencies, revising the 1983 Presidential Decree. The regulation of the organization of 'umrah travel by private agencies was tightened to prevent the combination of the cheap umrah with expensive bajj and to eliminate the abuse and mismanagement so often perpetrated by the private agencies. However, in general, there was no significant change in government policy concerning the umrah. The government certainly did not want to be involved in organizing its itinerary. This was probably caused by the fact that there is no quota imposed on the umrah pilgrimage, and it does not have to be undertaken in a certain set period which forces the pilgrims to travel in massive groups, but can be embarked on at any time (although regulated, the exceptions being the two months before and one month after the bajj month). Despite its somewhat distant attitude to 'umrah, it would be fair to say the Government actually did manage to control both the haij and 'umrah pilgrimages and the organization of their services.

\section{F. Hajj Fund}

The organization of hajj was a huge business that produced a lot of money. ${ }^{62}$ The most controversial matter related to this business was the existence of the 'ḅajj fund', which later, under Minister of Religious Affairs Tarmizi Taher, was called the Dana Ongkos Naik Haji (Hajj Cost Fund). ${ }^{63}$ Taher announced that the Dana Ongkos Naik Haji was an outcome of a 'pembenahan' (reform) of the financial management. ${ }^{64}$ The existence of such a fund dates back in fact to 1970 when Soeharto

${ }^{62}$ Zamakhsyari Dhofier, 'Dampak Ekonomi Ibadah Haji di Indonesia', Prisma, vol. 13 , no. 4,1984 , pp. 51-61.

${ }^{63}$ Under Minister Munawir Sjadzali, according to Amidhan, the then Director General of the Guidance of Islamic Community and Hajj Affairs, the fund was unofficially called 'Dana Brankas Besi' (Iron Box Fund). 'Haji dan Rimba Raya Dana Abadi', in S. Satya Dharma (ed.), Haji Kita: Fakta dan Problema Penyelenggaraan Haji di Indonesia 1990-2000 (Jakarta: Asosiasi Wartawan Muslim (AWAM) Indonesia, 2000), p. 93.

${ }^{64}$ Interview with Dr Tarmizi Taher, former Minister of Religious Affairs, Jakarta, 12 August 2004. I would like to thank Deden Ridwan for assisting me in interviewing him. 
established the Dana Sosial Kerohanian Presiden (President's SocioReligious Fund). The fund was built up by exacting a levy—some called it an illegal levy- on pilgrims and from profits or benefits accruing from hajj services. In 1986 the levy was Rp 40,000 per pilgrim; in 1987 Rp 30,000; in 1988 Rp 20,000. From 1989 to 1998, the levy remained at $\mathrm{Rp} 10,000$ per pilgrim. The other sources of the fund were bank interest accruing on the pilgrims' hajj costs $(\mathrm{ONH})$, and the refund of the insurance of pilgrims during the Gulf War (1991-1993). ${ }^{65}$

In 1996 a special board was established, namely the Badan Pengelola Dana Ongkos Naik Haji Indonesia (Board for the Management of the Indonesian Hajj Fund). ${ }^{66}$ All the profits from bajj services were retained as a hajj fund which officially used for the 'development of Muslim communities' and to assist Islamic organisations, especially those close to Soeharto and his political party, Golkar. ${ }^{67}$ On 14 August 1992, Minister Munawir Sjadzali handed over Rp 1,009,450,000 to the newly established Bank Muamalat Indonesia (BMI) as the contribution from pilgrims. Nevertheless, he did not agree that it should be made compulsory for forthcoming pilgrimages. ${ }^{68} \mathrm{It}$ was reported that the fund was also used to build hajj hospitals, ${ }^{69}$ as mentioned earlier, and Hajj Boarding Houses (asrama haji) in some cities where haijj embarked. However, Minister of Religious Affairs Tarmizi Taher did not mention the Dana Ongkos Naik Haji in his preface to the booklet 'Rumah Sakit Haji Jakarta'. Instead he said that the fund for the building of the hajj hospitals came from President Soeharto, the government of Saudi Arabia, generous Muslims, and the governments of the provinces in which the cities with the hospital were located. ${ }^{70}$ The government constantly reiterated that Dana Ongkos Naik Haji

${ }^{65}$ Dharma, Haji Kita, pp. 93-4.

${ }^{66}$ The board was based on Presidential Decree No. 62/1995 jo No. 81/1995, which was revised by the Presidential Decree No. 366/1996. Its office was at the Wisma Grahadi, owned by Soeharto, in Kuningan, South Jakarta. See 'Haji dan Rimba Raya Dana Abadi', in Dharma, Haji Kita, p. 94.

${ }^{67}$ Ibid.

${ }^{68}$ Aqsha et al, Islam in Indonesia, p. 122.

${ }^{69}$ Rumah Sakit, p. 14.

${ }^{70}$ Ibid., pp. 11-2. 
was: ' $\ldots$ collected from the ummah (pilgrims) and used for the betterment of the ummah'. Nevertheless, the existence of the Dana Ongkos Naik Haji was criticized by many parties, including NGOs, which claimed that the government had acted as a corporate business which collected benefits from its services. ${ }^{71}$

\section{G. Conclusion}

The above description has shown that hajj (and "umrah) had burgeoned into profitable religious tourism for both the government and private travel agencies. The government had enjoyed a monopoly of hajj services from 1969 and this did not end with the collapse of the New Order regime in 1998. The involvement of the private agencies in organizing 'bajj plus', which began in the 1980s, could be seen as a mere sub-organization of the business, rather than real demonopolization of hajj services. The failure of some reform efforts to improve the management of hajj (and 'umrah) services was mainly caused by the complex relations between religious piety on the part of the pilgrims on one hand and political as well as economic considerations on the part of Government and travel agencies on the other hand. Due to this fact, it is understandable that the reform efforts of hajj services could not easily conducted because these would greatly affect the very interests of both the Government and travel agencies. Becoming the regulator and at the same time the travel agency itself, the Government could not manage to reform bajj services appropriately.

${ }^{71}$ The name of this institution was later changed into Dana Abadi Ummat (DAU_Umma Perpetual Fund) in 1999, which is beyond the scope of this study. 
Governing Hajj: Politics of Islamic Pilgrimage Services in Indonesia

\section{BIBLIOGRAPHY}

Abdurrahman, Moeslim, On Haij Tourism: In Search of Piety and Identity in the New Order Indonesia, Ph.D. Dissertation, Urbana-Champaign: the Graduate College of the University of Illinois 2000.

Aqsha, Darul, Dick van der Meij, and Johan Meuleman, Islam in Indonesia: A Survey of Events and Developments from 1988 to March 1993, Jakarta: INIS, 1995.

Arsip Nasional, Biro Perjalanan Haji di Indonesia Masa Kolonial: Agen Herklots dan Firma Alsegoff \& Co, Jakarta: Arsip Nasional Republik Indonesia, 2001.

Bianchi, Robert R., Guests of God: Pilgrimage and Politics in the Islamic World, New York: Oxford University Press, 2004.

Buku Pegangan Penatar/Penyuluh Calon Haji, Jakarta: Direktorat Jenderal Bimbingan Masyarakat Islam dan Urusan Haji, Departemen Agama RI, 1988.

Bunga Rampai Perbajian II, Jakarta: Departemen Agama RI, Direktorat Jendral Bimbingan Masyarakat Islam dan Penyelenggaraan Haji, 2001.

Departemen Agama, Era Baru Perhajian Melalui Sistem Komputerisasi Haji Terpadu (SISKOHAT), Jakarta: Direktorat Jenderal Bimbingan Masyarakat Islam dan Urusan Haji Departemen Agama RI, 2000.

Dharma, S. Satya (ed.), Haji Kita: Fakta dan Problema Penyelenggaraan Haji di Indonesia 1990-2000, Jakarta: Asosiasi Wartawan Muslim (AWAM) Indonesia, 2000.

Dhofier, Zamakhsyari, "Dampak Ekonomi Ibadah Haji di Indonesia", Prisma, vol. 13, no. 4, 1984.

Douwes, Dick and Nico Kaptein (eds.), Indonesia dan Haji, Jakarta: INIS, 1997.

Harahap, Sumuran and Mursidi, Lintasan Sejarah Perjalanan Jemaah Haji Indonesia, Jakarta: Intimedia \& Insan Cemerlang, n.d.

Himpunan Peraturan Perundang-undangan Ditjen Bimas Islam dan Urusan Haji, Jakarta: Direktorat Jendral Bimbingan Masyarakat Islam dan Urusan Haji, Departemen Agama RI,1993. 
Himpunan Risalah Rapat Kerja Urusan Haji Selurub Indonesia ke-XIV di Cisarua Bogor, 27- 30 January 1982, Jakarta: Direktorat Jenderal Bimbingan Masyarakat Islam dan Urusan Haji, Departemen Agama RI, 1982.

Huda, Nur Cholis, Kisah Musibah Terowongan Mina, Surabaya: Bina Ilmu, 1990.

Ito, Makoto, 'Haji Tour under the Late New Order Regime in Indonesia: South Sulawesi Case', unpublished paper, n.d.

Jajasan Pedjalanan Hadji Indonesia, 22 Tabun Jajasan Perdjalanan Hadji Indonesia dan 50 Tabun Gerakan Perbaikan Perdjalanan Hadji Indonesia, Jakarta: Kantor Pusat Jajasan Pedjalanan Hadji Indonesia [PHI], 1972.

Kebijaksanaan Menteri Agama RI di Bidang Haji, Jakarta: Proyek

Perencanaan Peraturan Perundangan Keagamaan Biro Hukum dan Humas Departemen Agama, 1981/1982.

Laporan Penjelenggaraan Urusan Hadji 1385 H/1965-1966, Jakarta: Departemen Urusan Haji, 1966.

Laporan Penjelenggaraan Urusan Hadji Tabun 1388 H/1968/69 M dan Tabun 1389 H/1969/70 M, Jakarta: Direktorat Djendral Urusan Hadji, 1970.

Makky, Ghazy Abdul Wahed, "Pilgrim Accommodation in Mecca: Spatial Structures, Costs and National Origins", in Ziauddin Sardar and M.A. Zaki Badawi, Hajj Studies, Jeddah: The Hajj Research Centre, King Abdul Aziz University, Vol. 1, n.d.

Meulen, Daniel van der, "The Mecca Pilgrimage and its Importance to the Netherlands East Indies", Muslim World, vol. XXXI, 1941.

Nidjam, Achmad and Alatief Hanan, Manajemen Haji: Studi Kasus dan Telaah Implementasi Knowledge Workers, Jakarta: Zikrul Hakim, 2001.

Noer, Deliar, Administrasi Islam di Indonesia, Jakarta: PT. Rajawali, 1983.

Prawiranegara, Sjafruddin, Djangan Mempersulit Ibadab Hadji, Jakarta: DPP HUSAMI, 1970.

Raillon, François, 'The New Order and Islam, or the Imbroglio of Faith and Politics', Indonesia, no. 57, 1994. 
Risalah Musjawarah Kerdja Urusan Hadji Selurub Indonesia ke-II, Tgl. 27 s/d 304-1972 di Jakarta, Jakarta: Direktorat Djendral Urusan Hadji, 1972.

Rumah Sakit Haji Jakarta, Jakarta: Rumah Sakit Haji Jakarta, 1994.

Siregar, Amiruddin, "Bagaimana Haji 1978 dan Haji 1979”, Mimbar Ulama, 26, $3^{\text {rd }}$ year (January 1979).

Soeyono, Heru, Musibah Terowongan Al-Muaishim Haratul Lisan Mina, Klaten: Yayasan Ki Juru Mertani, 1990.

Tim Penyusunan dan Penerbitan Depatemen Agama RI, Perjalanan Ibadah Haji Pak Harto, Jakarta: Departemen Agama RI, 1993.

“Umroh Ditata, Haji Kena”, Tempo, 21 January 1984.

Vredenbregt, Jacob, “The Haddj: Some of its Features and Functions in Indonesia", Bijdragen tot de Taal- Land en Volkenkunde, vol. 